Research article

Open Access

\title{
Application of HPLC for the Simultaneous Determination of Aceclofenac, Paracetamol and Tramadol Hydrochloride in Pharmaceutical Dosage Form
}

\author{
Preeti ChandRA, Atul Singh RATHORE, \\ Sathiyanarayanan LOHIDASAN, Kakasaheb Ramoo MAHADIK *
}

Department of Pharmaceutical Chemistry, Poona College of Pharmacy, Bharati Vidyapeeth Deemed University, Erandwane, Pune-411038, Maharashtra, India.

* Corresponding author. E-mail: krmahadik@rediffmail.com (K. R. Mahadik)

Sci Pharm. 2012; 80: 337-351

doi:10.3797/scipharm.1108-04

Published: January $31^{\text {st }} 2012$

Accepted: January $31^{\text {st }} 2012$

Received: $\quad$ August $5^{\text {th }} 2011$

This article is available from: http://dx.doi.org/10.3797/scipharm.1108-04

(c) Chandra et al.; licensee Österreichische Apotheker-Verlagsgesellschaft m. b. H., Vienna, Austria.

This is an Open Access article distributed under the terms of the Creative Commons Attribution License (http://creativecommons.org/licenses/by/3.0/), which permits unrestricted use, distribution, and reproduction in any medium, provided the original work is properly cited.

\begin{abstract}
A simple, precise and accurate reversed-phase liquid chromatographic method has been developed for the simultaneous estimation of aceclofenac (ACF), paracetamol (PCM) and tramadol hydrochloride (TRM) in pharmaceutical dosage form. The chromatographic separation was achieved on a HiQ-Sil ${ }^{\mathrm{TM}} \mathrm{HS}$ C18 column ( $250 \times 4.6 \mathrm{~mm}$ i.d., $5 \mu \mathrm{m}$ particle size), kromatek analytical column at ambient temperature. The mobile phase consisted of 40: $60(\mathrm{v} / \mathrm{v})$; phosphate buffer ( $\mathrm{pH} \mathrm{6.0):} \mathrm{methanol.} \mathrm{The} \mathrm{flow} \mathrm{rate} \mathrm{was} \mathrm{set} \mathrm{to} 1.0 \mathrm{~mL} \mathrm{~min}^{-1}$ and UV detection was carried out at $270 \mathrm{~nm}$. The retention time $\left(t_{R}\right)$ for ACF, PCM and TRM were found to be $14.567 \pm 0.02,3.133 \pm 0.01$ and $7.858 \pm 0.02 \mathrm{~min}$, respectively. The validation of the proposed method was carried out for linearity, precision, robustness, limit of detection, limit of quantitation, specificity, accuracy and system suitability. The linear dynamic ranges were from 40-160 $\mu \mathrm{g} \mathrm{mL}{ }^{-1}$ for ACF, $130-520 \mu \mathrm{g} \mathrm{mL}^{-1}$ for PCM and $15-60 \mu \mathrm{g} \mathrm{mL}^{-1}$ for TRM. The developed method can be used for routine quality control analysis of titled drugs in pharmaceutical dosage form.
\end{abstract}

\section{Keywords}

Aceclofenac $\bullet$ Paracetamol $\bullet$ Tramadol hydrochloride $\bullet$ Method development $\bullet$ Validation $\bullet$ HPLC 


\section{Introduction}

Aceclofenac (ACF) (Fig. 1), [(\{2-[(2,6-dichlorophenyl)amino]phenyl\}acetyl)oxy]acetic acid [1], has analgesic properties and a good tolerability profile in a variety of painful conditions $[2,3]$. It is used for treatment of rheumatic disorders and soft-tissue injuries. ACF inhibits the enzyme cyclooxygenase and thus exerts its anti-inflammatory activity by inhibition of prostaglandin synthesis. This effect seems to be correlated with the appearance of acute protocolitis associated with nonsteroidal anti-inflammatory drug therapy [4-6].

Paracetamol (PCM) (Fig. 1), N-(4-hydroxyphenyl)acetamide, is a non-opiate, nonsalicylate, centrally and peripherally acting analgesic agent. It has only weak antiinflammatory effects. The most commonly consumed daily dose, $1000 \mathrm{mg}$, results in roughly $50 \%$ inhibition of both COX-1 and COX-2 in whole blood assays ex vivo in healthy volunteers. It has been suggested that COX inhibition might be disproportionately pronounced in the brain, explaining its antipyretic efficacy and its direct activity on the centre for the body temperature regulation in the hypothalamus [7-9].

Tramadol (TRM) (Fig. 1), 2-[(dimethylamino)methyl]-1-(3-methoxyphenyl)cyclohexanol, is a synthetic, centrally acting analgesic agent. It has mild opioid agonist properties and activates monoaminergic spinal inhibition of pain. Unlike other opioids, TRM has no clinically relevant cardiovascular or respiratory depressant activity. Furthermore, it does not have a prostaglandin inhibitory effect. It is used as racemate, whose two enantiomeres function in a complementary manner enhancing efficacy and improving tolerability. TRM was proven to be an effective and well tolerated analgesic agent for the prevention and treatment of moderate to severe pain of various origins, including the pain associated with labor [10-12].

Literature survey reveals that ACF is estimated individually or in combination with other drugs by HPLC $[13,14]$ and in plasma [15-17] by RP-HPLC. In addition, LC-MS [18], HPTLC [19-21] and stability-indicating HPLC and HPTLC methods $[22,23]$ have been reported.

For PCM RP-HPLC method [13, 14, 24-28], stability-indicating GC/MS method [29], HPLC/UV method for analysis of urinary and plasma/serum samples [30], LC-MS [31], plasma LC/MS/MS [32, 33] and HPTLC [20, 27, 28, 34-36] methods have been reported.

Similarly, for TRM RP-HPLC [24, 27, 37, 38], plasma RP-HPLC [39], RP-HPLC method for determination in human plasma, urine and saliva [40], LC-MS-MS [41, 42], LC determination in human breast milk [43] and TLC [44, 45] methods have been reported.

From the above literature survey it is very clear that no method has been reported for simultaneous determination of ACF, PCM and TRM by HPLC. Apshingekar et al. developed and validated a HPTLC method for simultaneous quantitation of Paracetamol, Tramadol and Aceclofenac in tablet formulation [45]. As for quantification HPLC seems to be more sensitive and precise than HPTLC. So, the present study is designed for the development and validation of simple, precise and accurate HPLC method for the simultaneous determination of ACF, PCM and TRM in pharmaceutical dosage form. The proposed method is validated as per ICH guidelines [46]. 
<smiles>O=C(O)COC(=O)Cc1ccccc1Nc1c(Cl)cccc1Cl</smiles>

ACF<smiles>CC(=O)Nc1ccc(O)cc1</smiles>

PCM<smiles>COc1cccc(C2(O)CCCCC2CN(C)C)c1</smiles>

TRM

Fig. 1. Structure of Aceclofenac (ACF), Paracetamol (PCM) and Tramadol (TRM)

\section{Experimental}

\section{Materials}

Working standards of pharmaceutical grade ACF (batch no. 1103/09), PCM (batch no. 2607/01), TRM (batch no. 7869/11) were obtained as a gift sample from Intas Pharmaceuticals. It was used without further purification and certified to contain $99.3 \%$, $99.6 \%$ and $100.0 \%(\mathrm{w} / \mathrm{w})$ on dry weight basis for ACF, PCM and TRM, respectively. Fixed dose combination tablets (Hifenac-TA, batch no. 188-21, Intas Pharmaceuticals Ltd.) containing $100 \mathrm{mg} \mathrm{ACF}, 325 \mathrm{mg}$ PCM and $37.5 \mathrm{mg}$ TRM were purchased from Kalyani Medicals, Pune, India. All chemicals and reagents of analytical grade were purchased from Merck Chemicals, Mumbai, India. High purity deionized water was obtained from Millipore, Milli-Q (Bedford, MA, USA) water purification system.

\section{Selection of analytical wavelength}

Stock solutions of drugs were prepared in methanol separately. UV spectrum of $10 \mu \mathrm{g}$ $\mathrm{mL}^{-1}$ of each individual drug was taken.

\section{Instrumentation and chromatographic conditions}

The HPLC system (Jasco corporation, Tokyo, Japan) which consisted of a Pump (model Jasco PU- 2080 Plus) along with manual injector sampler programmed at $20 \mu$ l capacity per injection was used. The detector consisted of UVI VIS (model Jasco UV 2075). LC separations were performed on a HiQ-Sil ${ }^{\text {TM }} \mathrm{HS}$ C18 column $(250 \times 4.6 \mathrm{~mm}$ i.d., $5 \mu \mathrm{m}$ particle size), kromatek, Essex CM6 1XN, Japan. Data was integrated using Jasco Borwin version 1.5, LC-Net II/ADC system. The mobile phase consisted of 40: $60(\mathrm{v} / \mathrm{v})$; phosphate buffer ( $\mathrm{pH}$ 6.0): methanol. The flow rate was set to $1.0 \mathrm{~mL} \mathrm{~min}^{-1}$ and UV detection was carried out at $270 \mathrm{~nm}$ at ambient temperature.

\section{Standard solutions and calibration graphs}

Stock standard solution containing ACF $\left(1000 \mu \mathrm{g} \mathrm{mL}^{-1}\right), \mathrm{PCM}\left(3250 \mu \mathrm{g} \mathrm{mL}^{-1}\right)$ and TRM $\left(375 \mu \mathrm{g} \mathrm{mL}^{-1}\right.$ ) was prepared by dissolving $50 \mathrm{mg}$ of ACF, $162.5 \mathrm{mg}$ of PCM and $18.75 \mathrm{mg}$ of TRM in water: methanol; 50: 50 (v/v) (denoted 'diluent') in a $50 \mathrm{~mL}$ volumetric flask. This was further diluted with diluent to obtain working standard solutions in a concentration range of $40-160 \mathrm{mg} \mathrm{mL}^{-1}$ (i.e. $40,60,80,100,120,140$, and $160 \mathrm{gg} \mathrm{mL}^{-1}$ ) for ACF, 130$520 \mu \mathrm{g} \mathrm{m}^{-1}$ (i.e. $130,195,260,325,390,455$ and $520 \mu \mathrm{g} \mathrm{mL}^{-1}$ ) for PCM and 15-60 $\mu \mathrm{g}$ $\mathrm{mL}^{-1}\left(15,22.5,30.0,37.5,45.0,52.5\right.$ and $\left.60 \mu \mathrm{g} \mathrm{mL}^{-1}\right)$ for TRM. Constant volume of $20 \mu \mathrm{L}$ injections were made for each concentration six times and chromatographed under the 
above mentioned conditions. The peak areas were plotted against the corresponding concentrations to obtain the calibration graphs. Linear calibration curves were generated using least-squares linear-regression analysis.

\section{Sample preparation}

To determine the content of ACF, PCM and TRM simultaneously in pharmaceutical dosage form Hifenac-TA, twenty tablets were weighed and finely powdered. An accurate weight of the powder equivalent to $100 \mathrm{mg}$ of ACF, $325 \mathrm{mg}$ of PCM and $37.5 \mathrm{mg}$ of TRM was weighed. This was then transferred into a $100 \mathrm{~mL}$ volumetric flask containing $20 \mathrm{~mL}$ methanol, sonicated for $10 \mathrm{~min}$. Added $20 \mathrm{~mL}$ water and sonicated for $10 \mathrm{~min}$. Then, diluted to $100 \mathrm{~mL}$ with diluent and sonicated for $20 \mathrm{~min}$. with intermittent shaking. This solution was filtered through a $0.45 \mu \mathrm{m}$ nylon syringe filter. $1 \mathrm{~mL}$ of the above solution was transferred to $10 \mathrm{~mL}$ volumetric flask and diluted to volume with diluent. The concentration achieved after the above dilution was $100 \mu \mathrm{g} \mathrm{mL}^{-1}$ of ACF, $325 \mu \mathrm{g} \mathrm{mL}^{-1}$ of PCM and 37.5 $\mu \mathrm{g} \mathrm{mL} \mathrm{m}^{-1}$ of TRM. A constant $20 \mu \mathrm{L}$ volume of sample solution was injected six times under the conditions described above. The peak areas were measured at $270 \mathrm{~nm}$ for ACF, PCM and TRM, respectively, and their concentrations in the samples were determined using multilevel calibration curve developed on the same HPLC system under the same conditions using linear regression equation.

\section{Method validation}

The optimized HPLC method was validated with respect to the following parameters. The validation was performed as per ICH guidelines [46].

\section{Precision}

Precision of the method was determined with the standard and the real sample. The intraday and inter-day variation for determination of ACF, PCM and TRM was carried out at three different standard concentration levels of 40,100, and $160 \mu \mathrm{g} \mathrm{mL}^{-1}$ for ACF, 130, 325 and $520 \mu \mathrm{g} \mathrm{mL}^{-1}$ for PCM and 15, 37.5 and $60 \mu \mathrm{g} \mathrm{mL}^{-1}$ for TRM. An amount of the sample powder equivalent to $100 \%$ of the label claim of ACF, PCM and TRM was accurately weighed and assayed. Method repeatability was achieved by repeating the same procedure six times on the same day for intra-day precision. The intermediate (interday) precision of the method was checked by performing the same procedure on different days under the same experimental conditions. The measurement of peak area for standard compound and repeatability of sample application were expressed in terms of relative standard deviation (\%R.S.D.) and standard error (S.E.).

\section{Robustness}

The robustness was studied by evaluating the effect of small but deliberate variations in the chromatographic conditions. The robustness of the method was studied by deliberately varying parameters like flow rate $\left( \pm 0.1 \mathrm{~mL} \mathrm{~min}^{-1}\right)$, mobile phase composition $( \pm 1 \%)$ and $\mathrm{pH}$ of the buffer ( \pm 0.1). Two analytical columns, one (HiQ-Sil ${ }^{\mathrm{TM}} \mathrm{HS}$ C18 column) from kromatek, Japan and the other (BDS Hypersil C18 column) from Thermo Scientific, USA, were used during the experiment. Robustness of the method was done at three different concentrations: 40,100 , and $160 \mu \mathrm{g} \mathrm{mL}^{-1}$ for ACF, 130, 325 and $520 \mu \mathrm{gL}^{-1}$ for PCM and 15, 37.5 and $60 \mu \mathrm{g} \mathrm{mL}{ }^{-1}$ for TRM. 


\section{Limit of detection (LOD) and limit of quantitation (LOQ)}

The detection limit of an individual analytical procedure is the lowest amount of analyte in a sample that can be detected but not necessarily quantitated as an exact value. The quantitation limit of an individual analytical procedure is the lowest amount of analyte in a sample that can be quantitatively determined with suitable precision and accuracy. LOD and LOQ of ACF, PCM and TRM were determined by calibration curve method. LOD and LOQ were calculated by using the following equations.

$$
L O D=\frac{3.3 \times \text { Sy.x }}{S} \quad L O Q=\frac{10.0 \times \text { Sy.x }}{S}
$$

Where, Sy.x is standard deviation of residuals from line; $\mathrm{S}$ is slope.

\section{Specificity}

Specificity is the ability of an analytical method to unequivocally assess the analyte in the presence of other components. Specificity was assessed by a qualitative comparison between chromatograms obtained from sample, standard, blank and placebo solutions. Diluent was injected as a blank. Placebo interference study was conducted by injecting placebo solution prepared from the excipients most commonly used in pharmaceutical formulations including starch, lactose monohydrate, aerosil, hydroxypropylmethylcellulose, titanium dioxide and magnesium stearate. It was determined by the complete separation of ACF, PCM and TRM with parameters like retention time $\left(t_{R}\right)$, resolution (Rs) and tailing factor $(\mathrm{T})$.

\section{System suitability}

The system suitability parameters with respect to theoretical plates $(\mathrm{N})$, peak symmetry $(T)$, capacity factor $\left(K^{\prime}\right)$, selectivity $(\alpha)$, HETP $(H)$ and resolution $(R s)$ between ACF, PCM and TRM peaks were defined.

\section{Accuracy}

Accuracy of the method was carried out by applying the method to drug sample to which known amounts of ACF, PCM and TRM standard powder corresponding to 50, 100 and $150 \%$ of label claim had been added (standard addition method). At each level of the amount six determinations were performed and the results obtained were compared with expected results.

\section{Results and Discussion}

\section{Selection of analytical wavelength}

ACF, PCM and TRM showed maximum absorbance at $277 \mathrm{~nm}, 248 \mathrm{~nm}$ and $217 \mathrm{~nm}$, respectively. $270 \mathrm{~nm}$ was selected as a detection wavelength (Fig. 2).

\section{Optimization of procedures}

The HPLC procedure was optimized with a view to develop a simultaneous assay method for ACF, PCM and TRM, respectively. The stock standard solution was diluted with diluent to a concentration of $100 \mu \mathrm{g} \mathrm{mL}^{-1}$ for ACF, $325 \mu \mathrm{g} \mathrm{mL}^{-1}$ for $\mathrm{PCM}$ and $37.5 \mathrm{\mu g} \mathrm{mL}^{-1}$ for 
TRM. Then, the standard solution was injected into a HiQ-Sil TM HS C18 column (250×4.6 $\mathrm{mm}$ i.d., $5 \mu \mathrm{m}$ particle size). Initially, acetate buffer was tried in acidic $\mathrm{pH}$, ammonium acetate buffer ( $\mathrm{pH}$ 4.0): methanol; 40: $60(\mathrm{v} / \mathrm{v})$, the ACF peak obtained with a retention time of more than 20 min and peak of PCM eluted out earlier than that of void volume. Also, the peak tailing of TRM was more than 1.5. To increase the $t_{R}$ of PCM and to decrease the $t_{R}$ of ACF at the same time, it was decided to increase the $\mathrm{pH}$ of the mobile phase more than 4.0 as suggested from the pKa values [ACF (pKa=4.7), PCM (pKa=9.5), TRM (pKa=9.41)]. The chromatographic conditions were also optimized by using different buffers like phosphate, acetate and citrate for mobile phase preparation. After a series of screening experiments, it was concluded that phosphate buffers gave better peak shapes than their acetate and citrate counterparts. Further to decrease the $t_{R}$ of ACF, gradient mobile phase consisting of phosphate buffer and methanol was also tried in various ratios but was ruled out because of the appearance of hump in baseline. Finally, in isocratic system different ratios of phosphate buffer and methanol at different $\mathrm{pH}$ were tried. To improve the peak shape, triethylamine was added. The optimum mobile phase was found to consist of 40: $60(\mathrm{v} / \mathrm{v})$; phosphate buffer (pH6.0): Methanol. Phosphate buffer ( $\mathrm{pH} \mathrm{6.0)}$ was prepared by dissolving $1.56 \mathrm{~g}$ sodium dihydrogen ortho-phosphate dihydrate and 0.35 $\mathrm{g}$ disodium hydrogen phosphate dihydrate in 1,000 $\mathrm{mL}$ LC-grade water. Triethylamine $(1 \mathrm{~mL})$ was added and the $\mathrm{pH}$ adjusted to 6.0 by addition of ortho-phosphoric acid. The flow rate was set to $1.0 \mathrm{~mL} \min ^{-1}$ and UV detection was carried out at $270 \mathrm{~nm}$. The retention time $\left(t_{R}\right)$ for ACF, PCM and TRM were found to be 14.650, 3.133 and $7.842 \mathrm{~min}$, respectively. Acceptable retention time $\left(t_{R}\right)$, plates, asymmetry and good resolution for ACF, PCM and TRM were obtained.

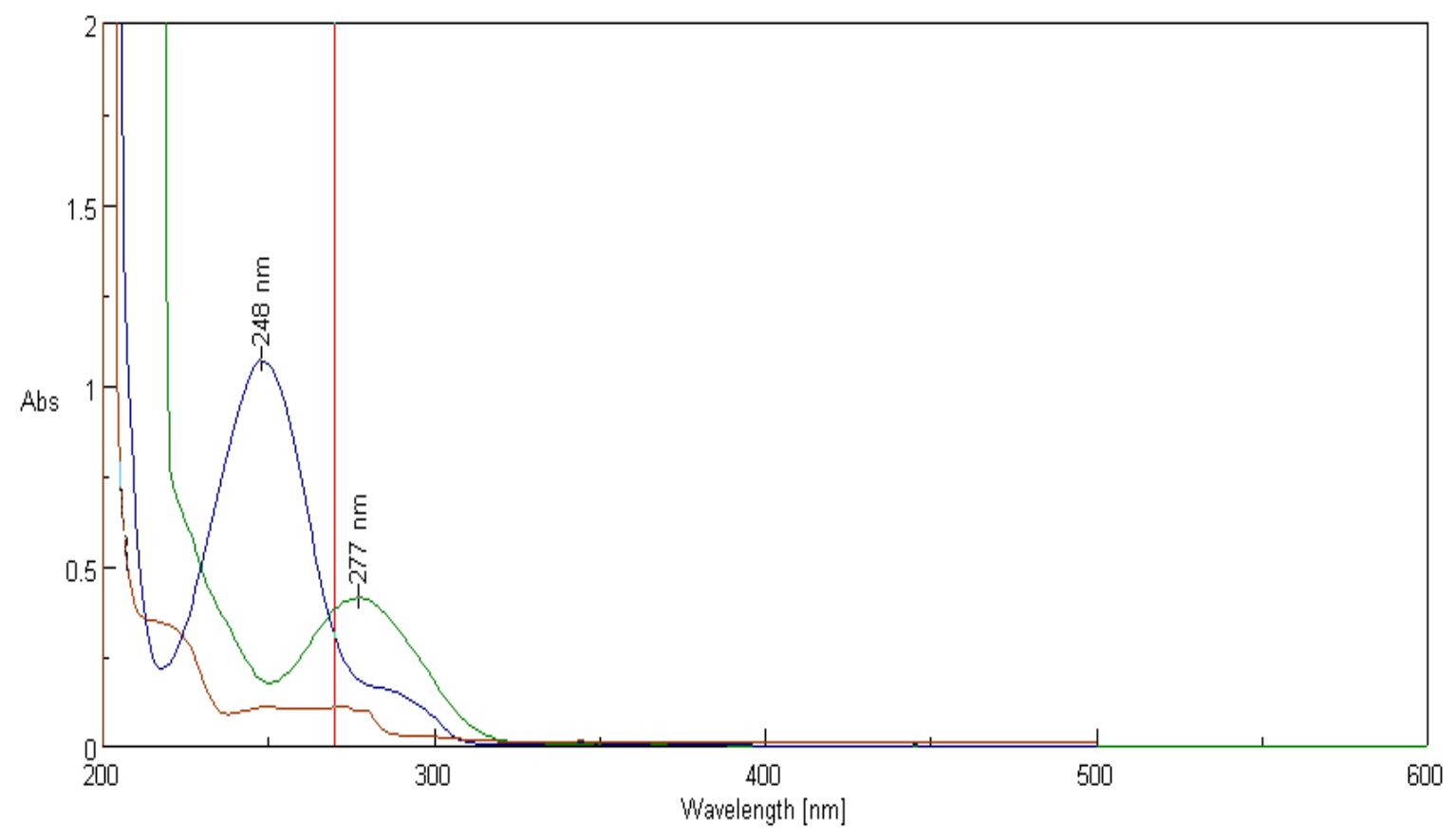

Fig. 2. UV spectrum overlay of ACF, PCM and TRM 


\section{Linearity}

Linear relationships were observed by plotting drug concentration against peak areas for each compound. ACF, PCM and TRM showed linear response in the concentration range of $40-160 \mu \mathrm{g} \mathrm{mL}^{-1}, 130-520 \mu \mathrm{g} \mathrm{mL}^{-1}$ and $15-60 \mu \mathrm{g} \mathrm{mL}^{-1}$, respectively. The corresponding linear regression equation was $y=43113 x-85483, y=16544 x+2993979$ and $y=7579 x-2200$, with square of correlation coefficient $\left(r^{2}\right)$ of $0.9998,0.9987$ and 0.9999 for ACF, PCM and TRM, respectively. Residual analysis was performed to ascertain linearity. The linearity of calibration graphs and adherence of the system to Beer's law was validated by high value of correlation coefficient. No significant difference was observed in the slopes of standard curves (Table 1).

Tab. 1. Linear regression data for calibration curves $(n=6)$

\begin{tabular}{lccc}
\hline Parameters & ACF & PCM & TRM \\
\hline Linearity range & $40-160 \mu \mathrm{mL}^{-1}$ & $130-520 \mu \mathrm{mL}^{-1}$ & $15-60 \mu \mathrm{mL}^{-1}$ \\
Slope \pm Standard error & $43113 \pm 298.83$ & $16544 \pm 269.35$ & $7579 \pm 26.72$ \\
Intercept \pm Standard error & $-85483 \pm 32185$ & $2993979 \pm 94284$ & $-2200 \pm 1079$ \\
Confidence limit of slope $^{\mathrm{a}}$ & 42345 to 43881 & 15851 to 17236 & 7510 to 7648 \\
$\mathrm{r}^{2}$ & 0.9998 & 0.9987 & 0.9999 \\
Correlation coefficient $(r)^{\text {Sy. }}$ & 0.9999 & 0.9993 & 1.0000 \\
a $^{\mathrm{a}}$ 95\% Confidence Intervals; ${ }^{\mathrm{b}}$ Standard deviation of residuals from line. & 720 \\
\hline
\end{tabular}

\section{Precision}

The \% R.S.D. values depicted in Table 2 show that proposed method provides acceptable intra-day and inter-day variation for ACF, PCM and TRM. The repeatability of sample application and measurement of peak area were expressed in terms of \% R.S.D. and were found to be $0.63,0.49$ for ACF, $0.33,0.96$ for PCM and $0.16,0.13$ for TRM.

Tab. 2. Intra-day and inter-day precision of ACF, PCM and TRM ( $n=6)$

\begin{tabular}{|c|c|c|c|c|c|c|c|}
\hline \multirow[b]{2}{*}{ Drug } & \multirow[b]{2}{*}{$\begin{array}{c}\text { Conc. } \\
\left(\mu g \mathrm{~mL}^{-1}\right)\end{array}$} & \multicolumn{3}{|c|}{ Repeatability (intra-day) } & \multicolumn{3}{|c|}{ Intermediate precision (inter-day) } \\
\hline & & $\begin{array}{l}\text { Found conc. } \\
\pm \text { S.D. }\end{array}$ & $\begin{array}{c}\% \\
\text { R.S.D. }\end{array}$ & S.E. & $\begin{array}{l}\text { Found conc. } \\
\pm \text { S.D. }\end{array}$ & $\begin{array}{c}\% \\
\text { R.S.D. }\end{array}$ & S.E. \\
\hline \multirow[t]{3}{*}{ ACF } & 40 & $39.57 \pm 0.16$ & 0.41 & 0.07 & $39.74 \pm 0.28$ & 0.70 & 0.11 \\
\hline & 100 & $99.19 \pm 0.25$ & 0.25 & 0.10 & $98.58 \pm 0.18$ & 0.18 & 0.07 \\
\hline & 160 & $160.55 \pm 1.34$ & 0.84 & 0.55 & $161.02 \pm 1.67$ & 1.04 & 0.68 \\
\hline \multirow[t]{3}{*}{ PCM } & 130 & $131.25 \pm 0.42$ & 0.32 & 0.17 & $131.86 \pm 0.85$ & 0.64 & 0.34 \\
\hline & 325 & $320.22 \pm 1.96$ & 0.61 & 0.80 & $319.01 \pm 1.10$ & 0.35 & 0.44 \\
\hline & 520 & $528.15 \pm 2.78$ & 0.53 & 1.13 & $526.33 \pm 1.50$ & 0.29 & 0.61 \\
\hline \multirow[t]{3}{*}{ TRM } & 15 & $15.16 \pm 0.03$ & 0.19 & 0.01 & $15.14 \pm 0.04$ & 0.25 & 0.02 \\
\hline & 37.5 & $37.44 \pm 0.07$ & 0.18 & 0.03 & $37.38 \pm 0.02$ & 0.06 & 0.01 \\
\hline & 60 & $60.09 \pm 0.05$ & 0.09 & 0.02 & $60.14 \pm 0.09$ & 0.15 & 0.03 \\
\hline
\end{tabular}




\section{Robustness}

Each factor selected (except columns from different manufacturers) to examine was changed at three levels $(-1,0$ and 1$)$. One factor at the time was changed to estimate the effect. Thus, replicate injections $(n=6)$ of mixed standard solution at three concentration levels were performed under small changes of chromatographic parameters (factors). Results, presented in Table 3, indicate that the selected factors remained unaffected by small variations of these parameters. The results from the two columns indicated that there is no significant difference between the results from the two columns.

Tab. 3. Robustness evaluation ${ }^{a}$ of the method $(n=6)$

\begin{tabular}{|c|c|c|c|c|c|c|c|}
\hline & & \multicolumn{3}{|c|}{ Retention time $\left(t_{R}\right)$} & \multicolumn{3}{|c|}{ Asymmetry (T) } \\
\hline Factor & Level & ACF & PCM & TRM & ACF & PCM & TRM \\
\hline \multicolumn{8}{|c|}{ Flow Rate $\left(\mathrm{mL} \mathrm{min}^{-1}\right)$} \\
\hline 0.9 & -1 & 15.336 & 3.316 & 7.958 & 1.27 & 1.22 & 1.01 \\
\hline 1.0 & 0 & 14.648 & 3.137 & 7.850 & 1.27 & 1.22 & 1.02 \\
\hline 1.1 & +1 & 13.950 & 2.972 & 7.768 & 1.26 & 1.23 & 1.00 \\
\hline Mean & S.D. & 14.645 & 3.142 & 7.859 & 1.27 & 1.22 & 1.01 \\
\hline ivica & & \pm 0.69 & \pm 0.17 & \pm 0.10 & \pm 0.01 & \pm 0.01 & \pm 0.01 \\
\hline \multicolumn{8}{|c|}{ Percentage of methanol in the mobile phase (v/v) } \\
\hline 59 & -1 & 15.213 & 3.156 & 7.923 & 1.29 & 1.17 & 1.03 \\
\hline 60 & 0 & 14.648 & 3.137 & 7.850 & 1.27 & 1.22 & 1.02 \\
\hline 61 & +1 & 14.186 & 3.092 & 7.762 & 1.27 & 1.21 & 1.02 \\
\hline & & 14.682 & 3.128 & 7.845 & 1.28 & 1.20 & 1.02 \\
\hline Mear & & \pm 0.51 & \pm 0.03 & \pm 0.08 & \pm 0.01 & \pm 0.03 & \pm 0.01 \\
\hline \multicolumn{8}{|c|}{$\mathrm{pH}$ of the buffer } \\
\hline 5.90 & -1 & 14.693 & 3.133 & 7.795 & 1.28 & 1.25 & 1.01 \\
\hline 6.00 & 0 & 14.648 & 3.137 & 7.850 & 1.27 & 1.22 & 1.02 \\
\hline 6.10 & +1 & 14.617 & 3.138 & 7.898 & 1.24 & 1.22 & 1.00 \\
\hline & & 14.653 & 3.136 & 7.848 & 1.26 & 1.23 & 1.01 \\
\hline vean & S.D. & \pm 0.04 & \pm 0.01 & \pm 0.05 & \pm 0.02 & \pm 0.02 & \pm 0.01 \\
\hline \multicolumn{8}{|c|}{ Columns from different manufacturers } \\
\hline HiQ-Sil $^{\mathrm{TN}}$ & US C18 & 14.648 & 3.137 & 7.850 & 1.27 & 1.22 & 1.02 \\
\hline BDS Hyp & rsil C18 & 14.650 & 3.142 & 7.858 & 1.34 & 1.28 & 1.08 \\
\hline & & 14.649 & 3.139 & 7.854 & 1.31 & 1.25 & 1.05 \\
\hline iviean & S.L. & \pm 0.001 & \pm 0.003 & \pm 0.006 & \pm 0.04 & \pm 0.04 & \pm 0.04 \\
\hline
\end{tabular}

\section{Limit of detection and limit of quantitation}

The LOD and LOQ were found to be 0.69 and $2.09 \mu \mathrm{g} \mathrm{mL} \mathrm{g}^{-1}$, respectively, for ACF, 0.57 and $1.74 \mu \mathrm{g} \mathrm{mL}^{-1}$, respectively, for PCM and 0.31 and $0.95 \mu \mathrm{g} \mathrm{mL}^{-1}$, respectively, for TRM.

\section{Specificity}

There is no peak interference of blank and placebo at the retention time of ACF, PCM and TRM, which indicates that the method is specific for the analysis in their pharmaceutical 
dosage form. The specificity of the method is illustrated in Fig. 3 where complete separation of ACF, PCM and TRM was noticed. The average retention time $\left(t_{R}\right) \pm S$.D. for ACF, PCM and TRM was found to be $14.567 \pm 0.02,3.133 \pm 0.01$ and $7.858 \pm 0.02 \mathrm{~min}$, respectively, for six replicates. Tailing factor for peaks of ACF, PCM and TRM was less than $2(T \leq 2)$ and resolution was satisfactory $(R s \geq 2)$. The peaks obtained were sharp and have clear baseline separation.

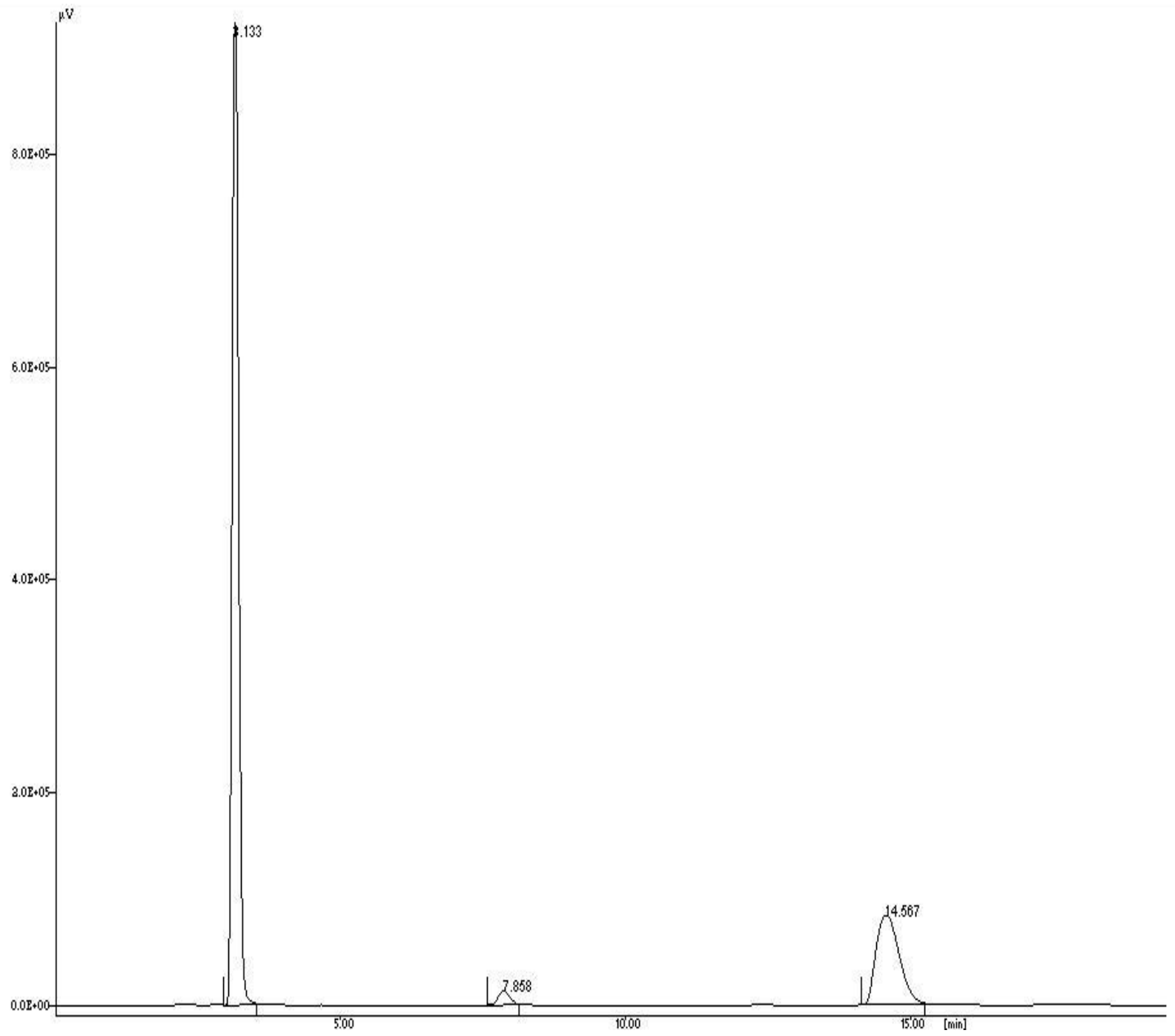

Fig. 3. Chromatogram of sample containing $325 \mu \mathrm{g} \mathrm{mL}^{-1}$ of $\mathrm{PCM}\left(t_{R} 3.133\right), 37.5 \mu \mathrm{g}$ $\mathrm{mL}^{-1}$ of TRM $\left(t_{R} 7.858\right)$ and $100 \mu \mathrm{g} \mathrm{mL}^{-1}$ of ACF $\left(t_{R} 14.567\right)$

\section{System suitability}

System suitability parameters including theoretical plates, peak asymmetry $(T)$, capacity factor (K'), selectivity $(\alpha)$ and resolution (Rs) between ACF, PCM and TRM peaks were calculated and summarized in Table 4. 
Tab. 4. System suitability parameters for PCM, TRM and ACF by the proposed HPLC method

\begin{tabular}{lcccc}
\hline Parameters & PCM & TRM & ACF & Reference values \\
\hline Theoretical plates $(\mathrm{N})$ & 6993.13 & 10375.28 & 9511.86 & $\mathrm{~N}>2000$ \\
Peak asymmetry $(T)$ & 1.30 & 1.07 & 1.33 & $T \leq 2$ \\
Capacity factor $\left(\mathrm{K}^{\prime}\right)$ & 0.18 & 1.96 & 4.53 & $1<\mathrm{K}^{\prime}<10$ \\
Selectivity $(\alpha)^{\mathrm{a}}$ & - & 10.75 & 2.31 & $\alpha>1$ \\
Resolution $(\mathrm{Rs}){ }^{\mathrm{a}}$ & - & 20.61 & 15.02 & $\mathrm{Rs} \geq 2$ \\
HETP $(\mathrm{H})^{\mathrm{b}}$ & 0.035 & 0.024 & 0.026 & - \\
\hline${ }^{\mathrm{a}}$ With respect to previous peak; ${ }^{\mathrm{b}}$ HETP (Height Equivalent to Theoretical Plate). \\
\hline
\end{tabular}

\section{Accuracy}

As shown from the data in Table 5 , satisfactory recovery $\%$ with small relative standard deviations (\%R.S.D.) were obtained at various added concentrations. The results indicate the method is highly accurate for simultaneous determination of the three drugs.

Tab. 5. Accuracy studies for the determination of (a) ACF (b) PCM (c) TRM ( $n=6)$

\begin{tabular}{|c|c|c|c|c|c|}
\hline $\begin{array}{l}\text { Excess drug } \\
\text { added to the } \\
\text { analyte (\%) }\end{array}$ & $\begin{array}{c}\text { Theoretical } \\
\text { content } \\
\left(\mu \mathrm{g} \mathrm{m}^{-1}\right)\end{array}$ & $\begin{array}{c}\text { Measured } \\
\text { conc. } \pm \text { S.D. }\end{array}$ & $\begin{array}{c}\text { Recovery } \\
\text { (\%) }\end{array}$ & \%.R.S.D. & S.E. \\
\hline \multicolumn{6}{|c|}{ ACF } \\
\hline 50 & 45 & $44.91 \pm 0.06$ & 99.80 & 0.14 & 0.02 \\
\hline 100 & 60 & $59.73 \pm 0.19$ & 99.55 & 0.32 & 0.08 \\
\hline 150 & 75 & $74.82 \pm 0.13$ & 99.76 & 0.17 & 0.05 \\
\hline \multicolumn{6}{|c|}{$\mathrm{PCM}$} \\
\hline 50 & 146.25 & $145.82 \pm 0.30$ & 99.71 & 0.21 & 0.12 \\
\hline 100 & 195 & $194.25 \pm 0.53$ & 99.62 & 0.27 & 0.22 \\
\hline 150 & 243.75 & $242.67 \pm 0.76$ & 99.56 & 0.31 & 0.31 \\
\hline \multicolumn{6}{|c|}{ TRM } \\
\hline 50 & 16.87 & $16.69 \pm 0.13$ & 98.93 & 0.76 & 0.05 \\
\hline 100 & 22.5 & $22.31 \pm 0.15$ & 99.16 & 0.67 & 0.06 \\
\hline 150 & 28.12 & $27.93 \pm 0.21$ & 99.32 & 0.75 & 0.09 \\
\hline
\end{tabular}

\section{Analysis of marketed pharmaceutical dosage form}

Using the proposed chromatographic method, assay of ACF, PCM and TRM in their tablets Hifenac-TA (label claim: $100 \mathrm{mg}$ ACF, $325 \mathrm{mg}$ PCM and $37.5 \mathrm{mg}$ TRM per tablet, B. No. 188-21, Intas Pharmaceuticals Ltd.) was carried out. Satisfactory results were obtained for the drugs in a good agreement with the label claims thereby suggesting that there is no interference from any of the excipients which are normally present in tablets. The recovery $\% \pm$ R.S.D. \% of six replicate determinations was $99.76 \pm 0.29$ for ACF, $99.57 \pm 0.37$ for PCM, and $99.18 \pm 0.57$ for TRM. 


\section{Conclusion}

The developed HPLC technique is precise, specific, robust and accurate. Statistical analysis proves that the method is suitable for routine analysis of ACF, PCM and TRM in pharmaceutical dosage form.

\section{Acknowledgement}

The authors thank Intas Pharmaceuticals Ltd., India for providing gift samples of ACF, PCM and TRM. The authors are thankful to AICTE for financial support for carrying out this research work.

\section{Authors' Statement \\ Competing Interests}

The authors declare no conflict of interest.

\section{References}

[1] Bodavari S.

The Merck Index.

14th edn, 2006; Merck, Whitehouse Station, 23, pp. 9566.

[2] Brogden RN, Wiseman LR.

Aceclofenac: A Review of its Pharmacodynamic Properties and Therapeutic Potential in the Treatment of Rheumatic Disorders and in Pain Management.

Drugs. 1996; 52: 113-124.

http://dx.doi.org/10.2165/00003495-199652010-00008

[3] Dooley M, Spencer CM, Dunn CJ.

Aceclofenac: a reappraisal of its use in the management of pain and rheumatic disease.

Drugs. 2001; 61: 1351-1378.

http://dx.doi.org/10.2165/00003495-200161090-00012

[4] Martel-Pelletier J, Cloutier JM, Pelletier JP.

Effects of aceclofenac and diclofenac on synovial inflammatory factors in human osteoarthritis.

Clin Drug Investig. 1997; 14: 226-232.

http://dx.doi.org/10.2165/00044011-199714030-00011

[5] Yamazaki R, Kawai S, Matsuzaki T, Kaneda N, Hashimoto S, Yokokura T, Okamoto R, Koshino T, Mizushima Y.

Aceclofenac blocks prostaglandin E2 production following its intracellular conversion into cyclooxygenase inhibitors.

Eur J Pharmacol. 1997; 329: 181-187.

http://dx.doi.org/10.1016/S0014-2999(97)10130-3

[6] Legrand E.

Aceclofenac in the management of inflammatory pain.

Expert Opin Pharmacother. 2004; 5: 1347-1357.

http://dx.doi.org/10.1517/14656566.5.6.1347

[7] Boutaud O, Aronoff DM, Richardson JH, Marnett LJ, Oates JA.

Determinants of the cellular specificity of acetaminophen as an inhibitor of prostaglandin $\mathrm{H}(2)$

synthases.

Proc Natl Acad Sci. 2002; 99: 7130-7135.

http://dx.doi.org/10.1073/pnas.102588199 
[8] Ouellet M, Percival MD.

Mechanism of acetaminophen inhibition of cyclooxygenase isoforms.

Arch Biochem Biophys. 2001; 387: 273-280.

http://dx.doi.org/10.1006/abbi.2000.2232

[9] Catella-Lawson F, Reilly MP, Kapoor SC.

Cyclooxygenase inhibitors and the antiplatelet effects of aspirin.

N Engl J Med. 2001; 345: 1809-1817.

http://dx.doi.org/10.1056/NEJMoa003199

[10] Scott LJ, Perry CM.

Tramadol: A review of its use in perioperative pain.

Drugs. 2000; 60: 139-176.

http://dx.doi.org/10.2165/00003495-200060010-00008

[11] Lee CR, McTavish D, Sorkin EM.

Tramadol. A preliminary review of its pharmacodynamic and pharmacokinetic properties, and therapeutic potential in acute and chronic pain states.

Drugs. 1993; 46: 313-340.

http://dx.doi.org/10.2165/00003495-199346020-00008

[12] Lehmann KA.

Tramadol for the management of acute pain.

Drugs. 1994; 47: 19-32.

http://dx.doi.org/10.2165/00003495-199400471-00005

[13] Vaidya VV, Singh GR, Choukekar MP, Kekare MB.

Simultaneous RP HPLC determination of aceclofenac, paracetamol and tizanidine in pharmaceutical preparations.

E J Chem. 2010; 7: 260-264.

[14] Pawar UD, Naik AV, Sulebhavikar AV, Datar TA, Mangaonkar KV.

Simultaneous determination of aceclofenac, paracetamol and chlorzoxazone by HPLC in tablet dose form.

E J Chem. 2009; 6: 289-294.

[15] Lee HS, Jeong CK, Choi SJ, Kim SB, Lee MH, Ko GI, Sohn DH.

Simultaneous determination of aceclofenac and diclofenac in human plasma by narrowbore HPLC using column-switching.

J Pharm Biomed. 2000; 23: 775-781.

http://dx.doi.org/10.1016/S0731-7085(00)00381-2

[16] Jin Y, Chen H, Gu S, Zeng F.

Determination of aceclofenac in human plasma by reversed-phase high performance liquid

chromatography.

Chin J Chromatogr. 2004; 22: 252-254.

http://www.ncbi.nlm.nih.gov/pubmed/15712910

[17] Hinz B, Auge D, Rau T, Rietbrock S, Brune K, Werner U.

Simultaneous determination of aceclofenac and three of its metabolites in human plasma by highperformance liquid chromatography.

Biomed Chromatogr. 2003; 17; 268-275.

http://dx.doi.org/10.1002/bmc.243

[18] Kang W, Kim EY.

Simultaneous determination of aceclofenac and its three metabolites in plasma using liquid

chromatography-tandem mass spectrometry.

J Pharm Biomed Anal. 2008; 46: 587-591.

http://dx.doi.org/10.1016/j.jpba.2007.11.009 
[19] Soni TG, Chotai NP, Patel PH, Hingorani L, Shah R, Patel N, Gandhi TR.

Evaluation of an optimum regression model for high-performance thin-layer chromatographic analysis of aceclofenac in plasma.

J Planar Chromatogr. 2009; 22: 101-107.

http://dx.doi.org/10.1556/JPC.22.2009.2.5

[20] Harikrishnan N, Gunasekaran V, Sathishbabu A, Rao GS, Roosewelt C.

Simultaneous estimation of aceclofenac and paracetamol by HPTLC in pure and pharmaceutical dosage form.

Asian J Chem. 2007; 19: 3918-3922.

[21] Sane RT, Menon SN, Mote M, Inamdar S, Menezes A.

High-performance thin-layer chromatographic determination of aceclofenac in the bulk drug and in pharmaceutical preparations.

J Planar Chromatogr. 2004; 17: 238-240.

http://dx.doi.org/10.1556/JPC.17.2004.3.15

[22] Bhinge JR, Kumar RV, Sinha VR.

A simple and sensitive stability-indicating RP-HPLC assay method for the determination of aceclofenac.

J Chromatogr Sci. 2008; 46: 440-444.

http://www.ncbi.nlm.nih.gov/pubmed/18492356

[23] El-Saharty YS, Refaat M, El-Khateeb SZ.

Stability-indicating spectrophotometric and densitometric methods for determination of aceclofenac.

Drug Dev Ind Pharm. 2002; 28: 571-582.

http://dx.doi.org/10.1081/DDC-120003453

[24] Jain D, Kachave RN, Bhadane RN.

Simultaneous estimation of tramadol hydrochloride, paracetamol and domperidone by RP-HPLC in tablet formulation.

J Liq Chromatogr Relat Technol. 2010; 33: 786-792.

http://dx.doi.org/10.1080/10826071003684224

[25] Selvan PS, Gopinath R, Saravanan VS, Gopal N.

Simultaneous estimation of levocetirizine, ambroxol, phenylpropanolamine and paracetamol in combined dosage forms by RP-HPLC method.

Asian J Chem. 2006; 18: 2591-2596.

[26] Rao RN, Narasaraju A.

Rapid separation and determination of process-related substances of paracetamol using reversedphase HPLC with photo diode array as a detector.

Anal Sci. 2006; 22: 287-292.

http://dx.doi.org/10.2116/analsci.22.287

[27] Gandhimathi M, Ravi TK.

RP-HPLC and HPTLC estimation of tramadol hydrochloride and paracetamol in combination.

Asian J Chem. 2008; 20: 4940-4942.

[28] Krishnamurthy R, Malve MK, Shinde BM.

Simultaneous determination of morphine, caffeine, and paracetamol in the urine of addicts by HPTLC and HPLC.

J Planar Chromatogr. 2000; 13: 171-175.

[29] Belal T, Awad T, Clark CR.

Stability-indicating simultaneous determination of paracetamol and three of its related substances

using a direct GC/MS method.

J AOAC Int. 2009; 92: 1622-1630.

http://www.ncbi.nlm.nih.gov/pubmed/20166578

[30] Soysa P, Kolambage S.

Rapid HPLC/UV method for analysis of urinary and plasma/serum paracetamol concentrations.

J Natn Sci Foundation Sri Lanka. 2010; 38: 131-137. 
[31] Li H, Zhang C, Wang J, Jiang Y, Fawcett JP, Gu J.

Simultaneous quantitation of paracetamol, caffeine, pseudoephedrine, chlorpheniramine and cloperastine in human plasma by liquid chromatography-tandem mass spectrometry.

J Pharm Biomed Anal. 2010; 51: 716-722.

http://dx.doi.org/10.1016/j.jpba.2009.10.009

[32] Hu L, Yang X, Wang X, Zhu J, Tong S, Cao G.

Rapid LC-APCI-MS-MS method for simultaneous determination of phenacetin and its metabolite paracetamol in rabbit plasma.

Chromatographia. 2009; 70: 585-590.

http://dx.doi.org/10.1365/s10337-009-1163-3

[33] Liao Q, Xie Z, Pan B, Zhu C, Yao M, Xu X, Wan J.

LC-MS-MS simultaneous determination of paracetamol, pseudoephedrine and chlorpheniramine in human plasma: Application to a pharmacokinetic study.

Chromatographia. 2008; 67: 687-694.

http://dx.doi.org/10.1365/s10337-009-1163-3

[34] Khatal LD, Kamble AY, Mahadik MV, Dhaneshwar SR.

Validated HPTLC method for simultaneous quantitation of paracetamol, diclofenac potassium, and famotidine in tablet formulation.

J AOAC Int. 2010; 93: 765-770.

http://www.ncbi.nlm.nih.gov/pubmed/20629373

[35] Yadav A, Singh R, Mathur S, Saini P, Singh G.

A simple and sensitive HPTLC method for simultaneous analysis of domperidone and paracetamol in tablet dosage forms.

J Planar Chromatogr. 2009; 22: 421-424.

http://dx.doi.org/10.1556/JPC.22.2009.6.6

[36] Dighe VV, Sane RT, Menon SN, Tambe HN, Pillai S, Gokarn VN.

Simultaneous determination of diclofenac sodium and paracetamol in a pharmaceutical preparation and in bulk drug powder by high-performance thin-layer chromatography.

J Planar Chromatogr. 2006; 19: 443-448.

http://dx.doi.org/10.1556/JPC.19.2006.6.7

[37] Kachhadia PK, Doshi AS, Ram VR, Joshi HS.

Validated LC method for simultaneous analysis of tramadol hydrochloride and aceclofenac in a commercial tablet.

Chromatographia. 2008; 68: 997-1001.

http://dx.doi.org/10.1365/s10337-008-0829-6

[38] Salmeron-Gacia A, Navas N, Martin A, Roman E, Cabeza J, Capitan-Vallvey LF.

Determination of tramadol, metamizole, ropivacaine, and bupivacaine in analgesic mixture samples by HPLC with DAD detection.

J Chromatogr Sci. 2009; 47: 231-237.

http://www.ncbi.nlm.nih.gov/pubmed/19298711

[39] Nobilis M, Kopecky J, Kvetina J, Chladek J, Svoboda Z, Vorisek V, Perlik F, Kunes J.

High-performance liquid chromatographic determination of tramadol and its O-desmethylated metabolite in blood plasma - Application to a bioequivalence study in humans.

J Chromatogr A. 2002; 949: 11-22.

http://dx.doi.org/10.1016/S0021-9673(01)01567-9

[40] Ardakani YH, Rouini MR.

Improved liquid chromatographic method for the simultaneous determination of tramadol and its three main metabolites in human plasma, urine and saliva.

J Pharm Biomed Anal. 2007; 44: 1168-1173.

http://dx.doi.org/10.1016/j.jpba.2007.04.012 
[41] Saccomanni G, Del Carlo S, Giorgi M, Manera C, Saba A, Macchia M.

Determination of tramadol and metabolites by HPLC-FL and HPLC-MS/MS in urine of dogs.

J Pharm Biomed Anal. 2010; 53: 194-199.

http://dx.doi.org/10.1016/j.jpba.2010.03.016

[42] Patel BN, Sharma N, Sanyal M, Shrivastav PS.

An accurate, rapid and sensitive determination of tramadol and its active metabolite

O-desmethyltramadol in human plasma by LC-MS/MS.

J Pharm Biomed Anal. 2009; 49: 354-366.

http://dx.doi.org/10.1016/j.jpba.2008.10.030

[43] Kmetec V, Roskar R.

HPLC determination of tramadol in human breast milk.

J Pharm Biomed Anal. 2003; 32: 1061-1066.

http://dx.doi.org/10.1016/S0731-7085(03)00209-7

[44] Krzek J, Starek M.

Quality assessment for tramadol in pharmaceutical preparations with thin layer chromatography and densitometry.

Biomed Chromatogr. 2004; 18: 589-599.

http://dx.doi.org/10.1002/bmc.361

[45] Apshingekar PP, Mahadik MV, Dhaneshwar SR.

Validated HPTLC Method for simultaneous quantitation of Paracetamol, Tramadol and Aceclofenac in tablet formulation.

Der Pharmacia Lettre. 2010; 2: 28-36.

[46] International Conference on Harmonization (ICH Q2 (R1).

Validation of Analytical Procedures: Text and Methodology, IFPMA, Geneva, Switzerland, 2005. 